\title{
Private International Law Rules in the Insolvency Regulation Recast: A Reform or a Restatement of the Status Quo?
}

\author{
by
}

\author{
Federico M. Mucciarelli*
}

The European Parliament, after a lengthy debate, has eventually approved a reform of Regulation 1346/2000 on cross-border insolvency proceedings (hereinafter, the 'Insolvency Regulation Recast'), which provides for significant innovations of the original Regulation, such as a EU-wide register of insolvencies and a new proceeding for insolvencies of corporate groups. The fundamental logic of the Regulation, however, does not change: the Recast does not harmonise insolvency rules at EU level and its goal is still selecting competent venues and applicable insolvency regimes. In many respects, the reform simply codifies CJEU's case law, with the aim of increasing legal certainty. The Insolvency Regulation Recast is however innovative regarding the definition of COMI, by repealing the causality relation between criterions of 'permanence' and 'ascertainability'. Eventually, the Recast aims at better coordinating secondary proceedings and main proceedings; in this regard, it introduces 'synthetic secondary proceedings', whereby the insolvency practitioner of a main proceeding undertakes to respect other Member States distributional criterions in order to avoid the opening of a secondary proceeding. The real impact of these innovations is however uncertain.

Table of Contents

ECFR 2016, 1-30

1. A short history of the Insolvency Regulation Recast . . . . . . . . . . . 2

2. Scope of the Insolvency Regulation . . . . . . . . . . . . . . 7

a. Pre-insolvency proceedings and over-indebted natural persons in the original Insolvency Regulation. . . . . . . . . . . . . . . . . . 7

b. Scope of the Insolvency Regulation Recast: a codification of CJEU's case law ......................... 10

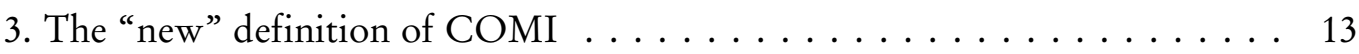

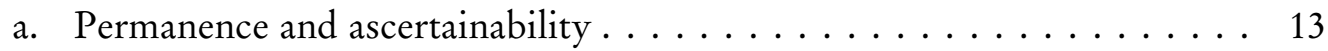

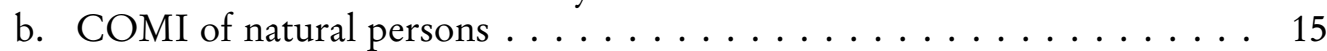

c. Opportunistic and fictive COMI relocations . . . . . . . . . . 17

4. Scope of insolvency law and insolvency-related actions . . . . . . . . . 20

* SOAS, University of London, Department of Financial and Management Studies - University of Modena \& Reggio Emilia, Department of Economics \& CEFIN. A previous version of this paper was presented at the SOAS, DeFiMS research seminar, on 17.3. 2015. I would like to thank Mimi Ajibade, Nick Foster and Mathias Siems for their comments. All mistakes and opinions are mine. 
a. Actions related to insolvency proceedings in the CJEU's case law . . . . 20

b. Scope of insolvency law rules and insolvency-related actions in the Insolvency Regulation Recast . . . . . . . . . . . . . . . . . . . . 23

5. Territorial proceedings and 'synthetic secondary proceedings' . . . . . . . . 24

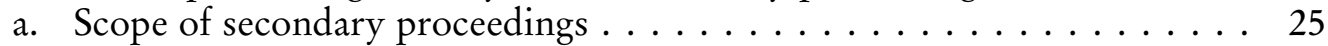

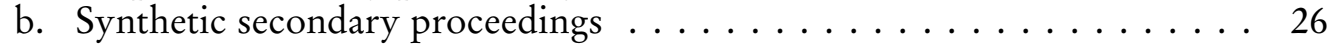

6. Conclusions: lights and shadows of a minimal approach . . . . . . . . . 29

\section{A short history of the Insolvency Regulation Recast}

The Annual Growth Survey 2015 of the EU Commission ${ }^{1}$ maintains that the creation of a single EU market "remains the most powerful engine of growth at EU level" and that consumers "should be able to benefit from an integrated single market which offers the same possibilities as their home markets". As a consequence of the removal of trade and legislative barriers, undertakings have expanded their intra-European activities and have weaved a web of crossborder connections with trade partners, investors and consumers throughout the European Union. Any significant insolvency of private undertakings or consumers, therefore, would strain this web and risk producing a 'dominoeffect' on many Member States. In this regard, the European Commission states that between 2009 and 2011, at the peak of the economic crisis, an average of 200,000 firms per year have become insolvent in the EU and that about $1 / 4$ of firms were involved in cross-border activities. ${ }^{2}$ Regarding those firms, any significant disparity or uncertainty of insolvency rules would make impossible for creditors to anticipate their risks, and would be a barrier in the way of the creation of single market in the EU. ${ }^{3}$

Having this in mind, one would expect insolvency rules be harmonised at EU level, but the reality is that Member States jealously keep their own domestic rules and proceedings. The reason for this resistance is that insolvency rules have distributional effects among debtors' stakeholders and are, therefore, embedded into local social security mechanisms and political dynamics. Con-

1 Annual Growth Survey 2015, Brussels, 28.11.2014, COM(2014) 902 final.

2 See: Commission Staff Working Document - Impact Assessment accompanying the document "Revision of Regulation (EC) No.1346/2000 on insolvency proceedings" (Strasbourg, 12.12.2012 SWD(2012) 416 final), hereinafter, the "Impact Assessment", page 17.

3 See: Bob Wessels, 'On the future of European Insolvency Law', 5 International Insolvency Law Review (2014) 310-332. See recently EU Commission Green 'Paper Building an Integrated Capital Markets Union', 18.2.2015 COM(2015) 63 final, page 24-25: "reducing these divergences [among insolvency regimes] could contribute to the emergence of pan-European equity and debt markets, by reducing uncertainty for investors needing to asses the risks in several member States." 
sequently, insolvency rules strictly depend on domestic legal culture and on national politics. ${ }^{4}$ The only legal mechanism approved in the EU with the aim of dealing with cross-border insolvencies is a Council Regulation of 2000 (hereinafter the 'Insolvency Regulation')5, which harmonises private international law criteria and coordinates insolvency procedures opened in different Member States. In order to increase its political acceptance in EU Member States, and to deal with practical difficulties that would arise if a pure universality principle was applied, the Insolvency Regulation follows a mechanism usually labelled 'modified universality', according to which: (a) the Member State where a debtor's centre of main interests (hereinafter 'COMI') is situated is competent to open a main insolvency proceeding; (b) courts of that State can seize all debtor's assets, regardless of their location, and can serve all creditors ${ }^{7}$; (c) after a main proceeding has been opened in the State of the COMI, 'secondary proceedings' limited to local assets can be opened in Member States in which establishments of the insolvent debtor are situated $;^{8}(\mathrm{~d})$ proceedings limited to local assets may be opened if a main proceeding can not be opened in the State of the COMI, or if this is requested by a local creditor ('independent proceedings'). ${ }^{9}$

In 2010 the European Parliament commissioned from INSOL - an academic and practitioner association - a report on the weaknesses of the Insolvency Regulation (hereinafter 'INSOL Report 2010'). ${ }^{10}$ The report that they produced stressed that Member States' insolvency regimes diverge from each other, and that these differences reduce predictability and provide incentives

4 See: Federico M. Mucciarelli, 'Not just efficiency: insolvency law in the EU and its political dimension', 14 European Business Organization Law Review, 175-200 (2013). Regarding the impact of culture, embedded in national traditions, see: Nicholas Foster, 'Company Law Theory in Comparative Perspective: England and France' American Journal of Comparative Lawe, 573-620 (2000).

5 Regulation (EC) No.1346/2000 on insolvency proceedings.

6 On difficulties in realising assets in Member States different than that of the COMI see: Christoph Paulus, Europäische Insolvenzverordnung. Kommentar, Frankfurt a. M. (2010) 59, at 27-28; Wessels, 'Contracting out of Secondary Insolvency Proceedings: The Main Liquidator's Undertaking in the Meaning of Article 18 in the Proposal to Amend the EU Insolvency Regulation', Brooklyn Journal of Corporate, Financial E Commercial Law (2014) pp. 241-242. On the advantages of opening territorial proceedings in order to deal with insolvent corporate groups see: Michel Menjucq, 'EC-Regulation No.1346/2000 on Insolvency Proceedings and Groups of Companies', European Company and Financial Law Review (2008) 142-143.

7 Article 3 (1) Insolvency Regulation.

8 Article 3 (3) Insolvency Regulation.

9 Article 3 (4) Insolvency Regulation.

10 Directorate General for Internal Policies, Policy Department C: Citizens' Rights and Constitutional Affairs Legal Affairs - Harmonisation of Insolvency Law at EU Level Note 2010. 
for opportunistic forum shopping. ${ }^{11}$ Such differences are related to: (a) criteria for the opening of an insolvency proceeding (in other words: the notion of 'insolvency'); (b) general stay of creditors' claims after the commencement of insolvency proceedings; (c) management of the insolvency proceedings; (d) creditor ranking and priorities; (e) filing and verification of claims; (f) responsibility for proposal, verification, adoption, modification and contents of reorganization plan; (g) avoidance and 'claw-back' actions; (h) termination of contracts and mandatory continuation of performance; (j) liability of directors, shadow directors, shareholders, lenders and other parties; (l) qualifications and eligibility for the appointment, licensing, regulation, supervision and professional ethics and conduct of insolvency representatives. Furthermore, the INSOL Report 2010 maintained that the rules on post-commencement finance were not adequate, that the absence of a EU register of insolvencies hinders cost-effective administrations and that "there are no rules on the coordination of insolvency proceedings with respect to different companies belonging to the same group of companies". As a consequence of this thorough analysis, the INSOL Report 2010 recommended the abandonment of a mere private international law logic and the harmonisation of following fields: (a) opening of the insolvency proceeding ${ }^{12}$; (b) filing and verification of claims in an insolvency proceeding ${ }^{13}$; (c) restructuring plans ${ }^{14}$; (d) avoidance of fraudulent and preference transfers ${ }^{15}$; (e) terminations of contracts ${ }^{16}$; (f) liability of directors and shareholders. ${ }^{17}$

Following the blueprint designed by the INSOL Report 2010, the European Parliament approved a resolution on the reform of the Insolvency Regula$\operatorname{tion}^{18}$, recommending the harmonisation of certain aspects of insolvency law in the EU. In addition, the European Parliament also recommended specific amendments aimed at broadening the scope of the Insolvency Regulation, at specifying the concepts of COMI and establishment, and at increasing coop-

11 Insol Report 2010, 26-27.

12 Insol Report 2010, 9-12; see also: Anna Maria Pukzsto, Harmonization of insolvency law at EU level with respect to opening of proceedings, claims filing and verification and reorganization plans (2011).

13 Insol Report 2010, 15-16.

14 Insol Report 2010, 16-17.

15 Insol Report 2010, 18-20; see also: Daniel Fritz, Note on Harmonisation of insolvency law at EU level: avoidance actions and rules on contracts (2011) and Ian Fletcher \& Bob Wessels, Harmonisation of Insolvency Law in Europe, Deventer 2012, 36-48.

16 Insol Report 2010, 20-22.

17 Insol Report 2010, 22-23.

18 European Parliament resolution of 15 November 2011 with recommendations to the Commission on insolvency proceedings in the context of EU company law (2011/ 2006(INI)) (the “European Parliament Resolution 2011”). 
eration among courts. Eventually, the European Parliament also suggested the creation of a pan-European insolvency register and the introduction of a special proceeding to deal with insolvencies of groups of companies. As we shall see, many of the proposals of the European Parliament have been adopted in the final version of the Insolvency Regulation Recast, except the proposal of partially harmonising insolvency rules.

In response to this resolution of the European Parliament, the EU Commission launched a public consultation on the reform of the Insolvency Regulation $^{19}$ and entrusted a consortium of the Universities of Heidelberg and Vienna with the task of drafting a comprehensive report evaluating the application of the Insolvency Regulation in each Member State and suggesting reform proposals. ${ }^{20}$ As a consequence of this intense consultative work, the Commission adopted a draft for a reform of the Insolvency Regulation (hereinafter, the 'Commission Proposal'). The Impact Assessment accompanying the Commission Proposal ${ }^{21}$ highlighted four main key problems of the Insolvency Regulation: 1) obstacles to the rescue of companies and to free movement of entrepreneurs and debt-discharged persons; 2) difficulties in determining the appropriate jurisdiction; 3) inefficiencies of cross-border procedures; 4) no legal framework addressing insolvencies of groups of companies. In its Impact Assessment, the Commission considered the option of partially harmonising Member States' insolvency regimes and of abolishing secondary proceedings. The Commission argued that the harmonisation solution are superior to alternative approaches, although repealing territorial proceedings could have negative impacts on local creditors. Nevertheless, the Commission rejected this option, arguing that it would "require an in-depth comparative-law analysis of national insolvency laws and procedures which would enable the Commission to identify the precise areas in which procedural harmonisation would be necessary and feasible, and not too intrusive to the national legislations and insolvency systems." 22

The Commission Proposal, therefore, followed a path of simply modernising the legal framework for cross-border insolvencies in the EU, by rejecting a partial harmonisation of insolvency rules and by keeping the logic of modi-

19 Consultation on the future of European Insolvency law, 12 June 2012, http://ec.europa.eu/justice/newsroom/civil/opinion/120326_en.htm

20 The full report was published as European Insolvency Law. Heidelberg - LuxembourgVienna Report (Hess - Oberhammer - Pfeiffer eds.), München, 2013 (hereinafter, the "Heidelberg - Vienna Report")

21 Impact Assessment Accompanying the document 'Revision of Regulation (EC) No. 1346/2000 on insolvency proceedings', Strassbourg 12.12.2012, [SWD(2012) 416 final]

22 Impact Assessment, page 44. 
fied universality. ${ }^{23}$ After a lengthy debate within EU institutions ${ }^{24}$, the reform proposal was converted in a recast of the Insolvency Regulation, eventually approved by the Council in March $2015^{25}$ and by the European Parliament on 20th June 2015 (hereinafter the 'Insolvency Regulation Recast'). ${ }^{26}$ Certain elements of the Insolvency Regulation Recast are definitively innovative: the reform mandates the creation of a EU-wide register of insolvencies, facilitates cross-border lodging of creditors' claims and introduces a new proceeding for insolvencies of corporate groups. Nevertheless, the Recast does not harmonise insolvency rules and does not alter the logic of the original Insolvency Regulation. ${ }^{27}$

The difficulties of harmonising insolvency rules are made clear by considering pre-insolvency and restructuring proceedings. The Commission acknowledged that regulatory discrepancies among Member States "lead to increased costs and uncertainty in assessing the risks of investing in another Member State, fragment conditions for access to credit and result in different recovery rates for creditors" and "may serve as disincentives for businesses wishing to establish themselves in different Member States". ${ }^{28}$ Nevertheless, the EU Commission decided not to level such differences and adopting a much softer

23 See Horst Eidenmüller, 'A New Framework for Business Restructuring in Europe: The EU Commission's Proposals for a Reform of the European Insolvency Regulation and Beyond', Maastricht Journal of European and Comparative Law (2013) 150 and Gerard McCormack, 'Reforming the European Insolvency Regulation: A Legal and Policy Perspective' 10 Journal of Private International Law (2014) 41-42.

24 European Parliament, Committee on Legal Affairs, 11. 9. 2013, Draft European Parliament Legislative resolution on the Council position at first reading; European Parliament, Plenary Sitting, 20.12.2013, Report, A70481/2013; European Parliament, legislative resolution of 5 February 2014 (COM(2012)0744 - C7-0413/2012 - 2012/ 0360(COD)) approving amendments to the Commission Proposal at first reading (hereinafter, the "European Parliament Resolution 2014").

25 Council of the European Union, Brussels, 17th March 2015, 16636/5/14 REV 5.

26 European Parliament, Committee on Legal Affairs, 11 May 2015, Draft Report European Parliament, legislative resolution of 20th May 2015 on the Council position at first reading with a view to the adoption of a regulation of the European Parliament and of the Council on insolvency proceedings (recast) (16636/5/2014 - C8-0090/2015 - 2012/ 0360(COD)) (Ordinary legislative procedure: second reading).

27 An harmonisation of insolvency regimes creeps into the Commission's normative materials under the guise of a recommendation on approximation of Member States' policies on companies restructuring proceedings and debt discharge: Commission Recommendation of 12 march 2014 on a new approach to business failure and insolvency. This Recommendation was accompanied by a report drafted by INSOL Europe: Study on a new approach to business failure and insolvency - Comparative legal analysis of the Member States' relevant provisions and practices, 12 May 2014 (hereinafter the "INSOL Report 2014 on restructuring proceedings").

28 Commission Recommendation Recital 4. 
approach, by releasing a recommendation without legally binding force on rescue proceedings. By issuing this recommendation, the Commission seems to test the water, in order to understand how Member States will react to a possible harmonisation of insolvency law.

This work will address the most significant private international law innovations of the Insolvency Regulation Recast: the scope of the Insolvency Regulation (Paragraph 2), the new concept of COMI (Paragraph 3), the scope of insolvency law and insolvency-related actions (Paragraph 4) and the rules coordinating main proceedings with territorial proceedings (Paragraph 5). The Insolvency Regulation Recast does not alter other rules, or alter them only minimally, which are relevant for selecting the applicable law, such as carve-outs and exceptions to the law of the COMI. ${ }^{29}$

\section{Scope of the Insolvency Regulation}

\section{a. Pre-insolvency proceedings and over-indebted natural persons in the original Insolvency Regulation}

The original Insolvency Regulation applied only to insolvent debtors and only to proceedings entailing debtors' dispossession. ${ }^{30}$ In recent years, however, pre-insolvency proceedings, most of which leave incumbent management in place, have gained relevance in many Member States. ${ }^{31}$ These proceedings normally aim at increasing the recovery rate and saving jobs. ${ }^{32}$ Curiously, some of them have been included in Annex A, although they do not fit in the scope of the Insolvency Regulation. This situation is clearly shown in a decision rendered by the CJEU in the case Bank Handlowy. ${ }^{33}$ In this case the question arose as to whether the opening of a French procedure of sauvegarde, which was included in Annex A, was to be recognised as a main proceeding in other Member States although this proceeding does not require a debtors' insolvency. ${ }^{34}$ In this regard, the CJEU and the Advocate General maintained that

29 Articles 8-18 Insolvency Regulation Recast (articles 5-15 Insolvency Regulation).

30 Article 1(1) Insolvency Regulation.

31 See: Burkhard Hess, Scope of the regulation, Heidelberg - Vienna Report, 25-28; INSOL Report 2014 on restructuring proceedings.

32 See the the clear words of Commission Recommendation 2014, Recital 1: "The objective of this Recommendation is to ensure that viable enterprises in financial difficulties, wherever they are located in the Union, have access to national insolvency frameworks which enable them to restructure at an early stage with a view to preventing their insolvency, and therefore maximise the total value to creditors, employees, owners and the economy as a whole."

33 C-116/11, Bank Handlowy w Warszawie SA v. Christianapol sp. z o.o., EU:C:2012:739.

34 Article L620-1 Code de Commerce [French Commercial Code]: "Sauvegarde proceed- 
the inclusion of a certain proceeding in Annex A is per se binding, also with regard to procedures that do not fit in the regulation's scope. ${ }^{35}$ Courts of a certain Member State cannot re-examine a debtor's insolvency once a main proceeding has been opened in another Member State, and can only open secondary proceedings. However, in contrast to the French sauvegarde, which was introduced in the French legislation in $2005^{36}$ and promptly included in Annex $\mathrm{A}^{37}$, other national rescue proceedings with similar features have not been included. This is clearly shown in the case Ulf Kazimierz, in which the CJEU stated that the Insolvency Regulation only applies to proceedings comprised in Annex A, and must not be applied to proceedings not included, even though they fit in the scope of the Insolvency Regulation. ${ }^{38}$ The relevance of Annex $\mathrm{A}$ is made clear by considering two UK restructuring proceedings that are largely used by non-UK debtors, the Company Voluntary Arrangement $(\mathrm{CVA})^{39}$ and the Scheme of Arrangement. ${ }^{40}$ Both proceedings are available to non-UK companies aiming at reaching an agreement with international debtors. Only CVAs, however, are included in Annex A, with the consequence that

ings are hereby established, which may be opened at the request of a debtor referred to in Article L.620-2 where and in so far as he is able to demonstrate the existence of difficulties, which he is not able to overcome, such as to lead to the cessation of payments.” The Heidelberg/Vienna Report reveals that both Belgium and Luxembourg provide for pre-insolvency proceedings that are included in Annex A but do not correspond to article 1(1) Insolvency Regulation.

35 See in particular the Conclusions of Advocate General Kokott, delivered of 24 May 2012, n. 48 and n. 49. Under the original Insolvency Regulation, however, this did not mean that Article 1(1) on its scope was completely irrelevant: it was a sort of blueprint for future inclusions in Annex A and could also lead to apply the Insolvency Regulation to proceedings not included in Annex A; see Gabriel Moss - Ian F. Fletcher - Stuart Isaacs, The EC regulation on insolvency proceedings : a commentary and annotated guide, $2^{\text {nd }}$ edition, Oxford, 2009, 232, n. 8.07; Christoph Paulus, Europäische Insolvenzverordnung. Kommentar, Frankfurt a. M. (2010) p. 94, n. 8.

36 Act 2005-845, 26 $6^{\text {th }}$ July 2005.

37 Council Regulation (EC) 694/2006, of 27 April 2006, amending the lists of insolvency proceedings, winding-up proceedings and liquidators in Annexes A, B and C to Regulation (EC) No. 1346/2000 on insolvency proceedings. Under article 45 of the Insolvency Regulation, Member States can ask the Council to amend the Annex by qualified majority. As a matter of fact, neither the Council, nor the Commission have ever checked whether any new proceedings included in Annex A meet the standards of Article 1(1) of the Insolvency Regulation.

38 C-461/11, Ulf Kazimierz Radziekski v Kronofogdenmyndigheten I Stokholm: EU:C: 2012:704.

39 SS 1-7 b Insolvency Act 1986. It is worth recalling that CVAs debtors can - although only under specific circumstances or in connection with an administration proceedingobtain a moratorium of creditors' claims: Roy Goode, Principles of corporate insolvency law, $4^{\text {th }}$ edition, London, 2011, $12-30$ to $12-39$.

40 Part 26 Companies Act 2006. 
non UK-debtors having their COMI in the UK can avail themselves of this restructuring procedure and that these arrangements are recognised in other Member States in compliance with the Insolvency Regulation. ${ }^{41}$ Schemes of arrangements, which probably do not fit in the scope of the regulation ${ }^{42}$, were intentionally not included in Annex A, with the consequence that non-UK companies can avail themselves of these procedures even when their COMI is not in the UK, provided that they have a 'sufficient' connection with the UK territory. ${ }^{43}$ This leaves, however, unresolved the question as to whether Schemes of Arrangement are to be recognised in other Member States. ${ }^{44}$

A further issue is related to insolvencies of private debtors. In the overwhelming majority of Member States, indeed, specific procedures address over-indebtedness of self-employed persons, private persons or consumers ${ }^{45}$ and in most of them debtors can obtain a complete discharge from residual unpaid debts. Although the Insolvency Regulation was already applicable to private debtors, in practice it did not effectively cover all personal insolvency schemes that Member States have developed in recent years. ${ }^{46}$ One reason is that some of these proceedings are quite recent and Annex A has not been updated yet; a

41 Indeed, CVAs apply also to non-UK debtors, provided that their centre of main interests is in the UK: S. 1 Insolvency Act 1986.

42 Schemes of arrangements are not necessarily 'collective' procedures: McCormack, 'Reforming' (note 23) 48.

43 Insolvency Act 1986 Section 122. See: Re Drax Holding Ltd [2004] 1 WLR 1049; La Seda de Barcelona SA [2010] EWHC 1104 (Ch) [Spanish company]; Trimast Holding Sarl v Tele Columbus GmbH [2010] EWHC 1944 (Ch) [German company]; Rodenstock [2011] EWHC 1104 (Ch) [German company]; Metrovacesa [2011] EWHC 1014 (Ch) [Spanish company]; SEAT Pagine Gialle s.p.a., [2012] EWHC 3686 (Ch) [Italian company]; Primacom Holding GmbH Holdings GmbH v Credit Agricole [2012] EWHC 164 (Ch) [German company]; APCOA Parking Holding GmbH [2014] EWHC 3849 (Ch) [German company]; Tele Columbus GmbH [2014] EWHC 249 [German companies] In these cases, courts granted order sanctioning schemes of arrangements since a sufficient connection existed with the UK territory, even though most creditors were not domiciled in the UK, and provided that a significant number of debts (including bonds) were governed by UK law.

44 Recent German and UK decisions maintain that orders of U.K. courts sanctioning a scheme of arrangement should be qualified a judgement under Brussels I Regulation and should be, therefore, recognised: BGH [German Federal Court], 15 February 2012, Equitable Life, NJW (2012) 2113 (obiter dictum); Rodenstock [2011] EWHC 1104 (Ch); Primacom Holding GmbH Holdings GmbH v Credit Agricole [2012] EWHC 164 (Ch). See: Christoph Paulus, 'Das Englische Scheme of Arrangement - ein neues Angebot auf dem europäischem Markt für außengerichtliche Restrukturierungen' ZIP (2011) 1077.

45 See: Hess, Scope of the Regulation (note 31) page 29: only four Member States do not provide for a proceeding aimed to address the over-indebtness of private individuals or self-employed persons (Bulgaria, Hungary, Romania, Spain). Impact Assessment EU Commission p. 13 et seq. 
more relevant reason, however, is that several debt-discharge proceedings do not require the appointment of a liquidator and, therefore, they do not fall within the scope of the Insolvency Regulation. ${ }^{47}$

\section{b. Scope of the Insolvency Regulation Recast: a codification of CJEU's case law}

The Insolvency Regulation Recast applies to any collective proceedings "commenced in a situation where there is only a likelihood of insolvency", provided that their goal is either of avoiding insolvency or of liquidating a debtor's business. ${ }^{48}$ Therefore, debtors' insolvency is not a necessary pre-requisite. Both insolvency and pre-insolvency proceedings should fit in one of the categories enumerated in article 1(1) of the Insolvency Regulation Recast. The first category, which was already foreseen in the original version of the Insolvency Regulation, comprehends proceedings in which the debtor is divested of the assets and a practitioner is appointed. ${ }^{49}$ The second case comprehends all proceedings in which debtors are not divested of their assets, provided that their affairs are subject to control or supervision by a court ${ }^{50}$. A significant innovation is the third category, which comprehends any proceedings in which a debtor can obtain a moratorium of creditors' claims in order to facilitate negotiations ${ }^{51}$. These proceedings should provide for "suitable measures to protect the general body of creditors" and, if no agreement is reached with creditors, they should lead to an insolvency procedure of another kind. ${ }^{52}$ More generally, the Insolvency Regulation Recast also applies to proceedings that do not entail the appointment of a liquidator, provided that

47 Impact Assessment EU Commission p. 14.

48 Article 1(2) Insolvency Regulation Recast. The reform also clarifies it applies to procedures whose purpose is a debtor's "rescue, adjustment of debt, reorganisation or liquidation", which was implicit in the original version of the regulation: Article 1(1) Insolvency Regulation Recast.

49 Article 1(1)(a) Insolvency Regulation Recast.

50 Article 1(1)(b) Insolvency Regulation Recast. This second hypothesis, like the first hypothesis, relies upon an active role of national courts. See Commission Proposal 2012, Article 1(1)(b).

51 Article 1(1)(c) Insolvency Regulation Recast. This case was foreseen neither in the Commission Proposal, nor in the European Parliament Resolution 2014. If a court of the competent Member State orders a moratorium, in order to allow negotiations between a debtor and his creditors, other Member States should recognise this decision under Article 32 of the Insolvency Regulation Recast (formerly Article 25 Insolvency Regulation).

52 Therefore, the Insolvency Regulation Recast includes both pre-insolvency proceedings that serve as first step to a full proceeding, as well as cases in which a full proceeding is opened only if pre-insolvency negotiation' attempts failed. See INSOL Report 2014 on restructuring proceedings page 24 . 
either (a) assets and affairs of the debtor are "subject to control or supervision of a court" 53 , or (b) suitable measures aimed at protecting creditors are available. ${ }^{54}$ This enlarged scope comprehends most personal insolvency and debtdischarge procedures that Member States have developed. The expanded scope of the Insolvency Regulation Recast shifts the scope of Brussels I Regulation on recognition and enforcement of civil proceedings ${ }^{55}$. The Brussels I Regulation, indeed, does not apply to "bankruptcy, proceedings relating to the winding-up of insolvent companies or other legal persons, judicial arrangements, compositions and analogous proceedings". ${ }^{56}$ Therefore, the Brussels I Regulation and the Insolvency Regulation are mutually exclusive and their scopes should be aligned. ${ }^{57}$ Consequently, the inclusion of pre-insolvency procedures in the scope of the Insolvency Regulation also alters the scope of the Brussels I Regulation. ${ }^{58}$

What is particularly interesting is the explicit statement that Annex $\mathrm{A}$ is binding. ${ }^{59} \mathrm{On}$ the one hand, the Regulation applies to any national procedure listed in that Annex, "without any further examination [...] regarding whether the conditions set out in this Regulation are fulfilled"; on the other hand their rules must not be applied to procedures that are not listed in Annex A. ${ }^{60}$ The Insolvency Regulation Recast, in practice, codifies CJEU's decisions rendered in the cases Bank Handlowy and Ulf Kazimierz on the binding force of Annexes to the Insolvency regulation. At the same time, a number of preinsolvency rescue proceedings have been included in Annex A, with the relevant exception of the UK schemes of arrangement. ${ }^{61}$

The binding force of Annex A, however, makes Article 1(1) partially redundant. ${ }^{62}$ Article 1(1) can still play a role as a blueprint that should be taken into

53 Article 1(1)(b) Insolvency Regulation Recast.

54 Article 1(1)(c) Insolvency Regulation Recast.

55 Regulation (EU) 1215/2012 of the European Parliament and of the Council of 12 December 2012 on jurisdiction and the recognition and enforcement of judgments in civil and commercial matters (recast) ('Brussels I Regulation Recast').

56 Article 1(2)(b) Brussels I Regulation Recast.

57 C-157/13, Nickel E Goeldner Spedition GmbH v. 'Kintra' UAB (EU:C:2014:2145).

58 Jonathan Fitchen, comment to Art. 2(b) Brussels I Regulation Recast, in Dickinson Lein (eds.) The Brussels I Regulation Recast (Oxford: 2015), at p. 73.

59 Article 1(3) Insolvency Regulation Recast.

60 Recital 9 Insolvency Regulation Recast.

61 For instance, the Annex A now comprehends the Skuldsanering, a Swedish proceeding on debt relief of private persons which was not included in the original version of Annex A, and that was made object of a decision of the CJEU: see: C-461/11, Ulf Kazimierz Radziekski v Kronofogdenmyndigheten I Stokholm [2012].

62 See: INSOL, Revision of the Insolvency regulation - Proposals by INSOL 2012, article 1 (see pages 25 et seq.), which suggested that the scope of the regulation should coincide with the list of proceedings included in Annex A. 
account when new proceedings are in the process of being included in Annex A. Consequently, the relevance of article 1(1) also depends on the proceeding for amending Annex A. Under the original version of the Insolvency Regulation, the Council, acting by qualified majority on initiative of a Member State or the Commission, had the power of amending Annexes. ${ }^{63}$ Therefore, Member States could decide whether own domestic proceedings were to be included into Annex A or not. ${ }^{64}$ In the Commission Proposal, the amending power was vested in the Commission at Member States' request; therefore Member States retained a 'negative' filter power and could decide not to include domestic proceedings into Annex A, while the 'positive' decision on whether including a proceeding was shared between Member States and the Commission. ${ }^{65}$ The European Parliament Resolution 2014 accepted the logic of the Commission Proposal, but suggested that Member States could only include proceedings that fit in the scope laid down in Article 1(1). ${ }^{66}$ Furthermore, the European Parliament also proposed that Member States should notify the Commission "of any substantial changes affecting their national rules on insolvency proceedings". ${ }^{67}$ Surprisingly, after an intense debate in Council meetings ${ }^{68}$, article 45 was deleted and was not replaced by any other special proceeding for amending Annex A. The real political reason for this innovation is quite obscure. With certainty, under the Insolvency Regulation Recast, Annexes can be amended only by ordinary legislative proceeding, which makes the system much more rigid and not able to adapt promptly to evolutions of Member States' legislations.

63 Article 45 Insolvency Regulation.

64 Hess, Scope of the regulation (note 31) at 28. See also the response of the City of London Law Society, to the Commission's consultation, which suggested not to alter this framework and recommending "that the decision as to which procedures to include should be made at the national level": (http://ec.europa.eu/yourvoice/ipm/forms/dispatch?userstate=DisplayPublishedResults\&form=Insolvency).

65 Article 45 Commission Proposal. See Gerard McCormack, 'Reforming' (note 23) 46 (very critical).

66 European Parliament Resolution 2014, amendment 66.

67 Amendment 67.

68 See the following meetings of the EU Council of the EU: $2^{\text {nd }}$ May 2014, 9429/14, offering the deletion of article 45 as just one of several regulatory options; $16^{\text {th }}$ May 2014, 9776/14, in which the deletion of article 45 does not appear as an option; 23 May $2014,10144 / 44$, in which the solution of deleting article 45 is the sole option adopted; proposal by the Presidency of the EU Council on Article 45, 10th June 2014, 1068/14, which suggests three alternative solutions, two of which including a deletion of Article 45 . Article 45 was finally deleted in the political compromise of $20^{\text {th }}$ November 2014, 1414/14. 


\section{The "new" definition of COMI}

Main insolvency proceedings are governed by the Member State where a debtor's centre of main interests (or 'COMI') is situated. The COMI is considered a viable choice-of-law and jurisdiction criterion, which allows the country mostly affected by a debtor's insolvency to govern the insolvency proceeding. ${ }^{9}$ The original Insolvency Regulation did not provide for a definition of COMI, but Recital 13 clarified that the place where debtors conduct "the administration of [their] interests on a regular basis and is therefore ascertainable by third parties" was deemed their COMI. ${ }^{70}$ The Insolvency Regulation Recast acknowledges the relevance of the criterions of permanence and ascertainability, which are now included in the definition of COMI. According to this new definition, indeed, the "centre of main interests shall be the place where the debtor conducts the administration of its interests on a regular basis and which is ascertainable by third parties." ${ }^{11}$

\section{a. Permanence and ascertainability}

A closer view reveals that the new definition of COMI partially diverges from old Recital 13. In old Recital 13, the criterions of permanence and ascertainability were linked by the adverb 'therefore' (or similar constructions in other languages indicating a causality relation ${ }^{72}$ ), which indicated that ascertainability was a consequence of a permanent central management, or, in other word, that a debtor's central management was ascertainable by third parties precisely because it had gained a certain time-continuity. ${ }^{73} \mathrm{~A}$ consequence was that a

69 Paulus, Europäische Insolvenzverordnung (note 35) 127 n. 20.

70 See: Miguel Virgos \& Francisco Garcimartin, The European Insolvency Regulation: Law and Practice, Kluwer 2004, 39: Recital 13 is the legal definition of COMI.

71 Article 3(1) Insolvency Regulation Recast.

72 Here are the versions that I can directly check: (a) Italian: "e pertanto riconoscibile dai terzi"; (b) German: "und damit für Dritte feststellbar ist"; (c) French: "et qui est donc vérifiable par les tiers"; (d) Portuguese: "pelo que é determinà vel por terceiros"; (e) Spanish: "y que, por consiguiente, pueda ser averiguado por terceros"; (f) Dutch: "en die daardoor als zodanig voor derden herkenbaar is". It is realistic to assume that other languages also use similar wordings.

73 Bob Wessels, International insolvency law, $3^{\text {rd }}$ edition, Deventer, 2012, paragraph 10546; Paschalis Paschalidis, Freedom of establishment and private international law for corporations, (Oxford 2012) 173. See also Irish Bank Resolution Corp Ltd v Quinn [2012] NICh $1=$ [2012] B.C.C. 608 (Deeny J) at paragraph 26: "not disregarding the use of 'therefore' in recital 13. That implies that the administration of interests will be ascertainable by third parties for that very reason. But in fact the latter depends on how that administration is conducted (e.g. covertly or overtly)." 
COMI's permanence could be inferred from its ascertainability. ${ }^{74}$ Therefore, the criterion of ascertainability has gained a paramount relevance in CJEU's decisions rendered in the cases Eurofood ${ }^{75}$ and Interedil. ${ }^{76}$ This is clearly emphasized by AG Jacobs in his opinion to the Eurofood case, in which he clarified that "it is because the corporation's head office functions are exercised in a particular Member State that the centre of main interests is ascertainable there". ${ }^{77}$ Since a COMI's ascertainability was consequence of a head office's presence in a certain State, it was to be assessed with objective criterions. Therefore, creditors' subjective perception as to the location of a debtor's COMI did not play a paramount role. ${ }^{78}$ According to the CJEU, indeed, the requirement of ascertainability is met "where the material factors taken into account for the purpose of establishing the place in which the debtor company conducts the administration of its interests on a regular basis have been made public or, at the very least, made sufficiently accessible to enable third parties, that is to say in particular the company's creditors, to be aware of them". ${ }^{79}$

The Insolvency Regulation Recast replaces the adverb 'therefore' with the conjunction 'and', which does not imply a causality relation between 'permanence' and 'ascertainability'. ${ }^{80}$ Therefore, the criterion of ascertainability has

74 Paschalidis, Freedom of establishment (supra note 73) 178.

75 The presumption in favour of the registered office "can be rebutted only if factors which are both objective and ascertainable by third parties enable it to be established that an actual situation exists which is different from that which locating it at that registered office is deemed to reflect": Case C-341/04, Eurofood IFSC Ltd [2006] ECR I-1078, at paragraph 34.

76 The presumption may be rebutted "where, from the viewpoint of third parties, the place in which a company's central administration is located is not the same as that of its registered office": Case C-396/09, Interedil Srl [2011] at paragraph 51. The CJEU, therefore, dismissed the opposite "mind of management" theory, according to which the presumption was rebutted by simply proving that a debtor' head office is situated elsewhere, regardless of whether third parties could ascertain this discrepancy: $R e$ Stanford International Bank Ltd [2009] EWHC 1441.

77 Opinion of AG Jacobs, 27 September 2005, 113

78 Virgos \& Garcimartin, The European Insolvency Regulation (supra note 70) 42.

79 Interedil at paragraph 49. In the Commission Proposal one more Recital was extracted from the Interedil decision (Recital 13 a): "it should not be possible to rebut the presumption where the bodies responsible for the management and supervision of a company are in the same place as its registered office and the management decisions are taken there in a manner ascertainable by third parties". Interestingly, this sentence has been deleted from the final version of the Reform under an explicit request of the European Parliament: European Parliament, Resolution 2014, amendment 6.

80 This amendment was already embodied in the Commission Proposal 2012, and was never challenged by the European Parliament. In the same languages mentioned before, this norm reads now in the same way as in English: (a) Italian: "Il centro degli interessi principali è il luogo in cui il debitore esercita la gestione dei suoi interessi in modo abituale 
become independent from the criterion of permanence, and these elements are to be proved separately. We shall see hereunder that this new definition might have an impact upon forum shopping cases. ${ }^{81}$

Furthermore, the question arises as to whether a COMI's ascertainability is still based upon an objective criterion. The answer can probably be found in a new Recital to the regulation, which clarifies that the presumption that companies' COMI coincide with their registered office can be rebutted "if a comprehensive assessment of all the relevant factors establishes, in a manner that is ascertainable by third parties, that the company's actual centre of management and supervision and of the management of its interests is located in that other Member State." 82 This Recital seems indicating that the assessment of whether a debtor's COMI is ascertainable is to be conducted by using objective criterions, as it was before the reform. On the other hand, however, Recital 27 specifies that "special consideration should be given to the creditors and their perception as to where a debtor conducts the administration of his interests" and seems focussing on creditors' subjective perception. ${ }^{83}$ The contradiction, however, is only illusory: Recital 27 , indeed, only aims at clarifying that creditors are the sole relevant third parties, while Recital 29 deals with assessment criterions, which remain based upon objectivity.

\section{b. COMI of natural persons}

Natural persons' COMI is often uncertain. The first reason is that natural persons can relocate their activities or residence more easily than companies

e riconoscibile dai terzi"; (b) German, "Mittelpunkt der hauptsächlichen Interessen ist $\overline{d e r}$ Ort, an dem der Schuldner gewöbnlich der Verwaltung seiner Interessen nachgeht und der für Dritte feststellbar ist"; (c) French: "Le centre des intérêts principaux correspond au lieu où le débiteur gère habituellement ses intérêts et qui est vérifiable par des tiers"; (d) Portuguese: "O centro dos interesses principais é o local em que o devedor exerce habitualmente a administração dos seus interesses de forma habitual e cognoscivel por terceiros; (e) Spanish: "El centro de intereses principales será el lugar en el que el deudor lleve a cabo de manera habitual y reconocible por terceros la administración de sus intereses"; (f) Dutch: "Het centrum van de voornaamste belangen is de plaats waar de schuldenaar gewoonlijk het beheer over zijn belangen voert en die als zodanig voor derden herkenbaar is".

81 See paragraph 3.3 hereunder.

82 Recital 29 Insolvency Regulation Recast.

83 Recital 27 Insolvency Regulation Recast. See also Council of the European Union, Statement of the Council's Reason, Brussels, 17 March 2015 (OR. en) 16636/5/14 REV 5 ADD 1, paragraph 17: "special consideration should be given to creditors and to their perception as to where the debtor conducts the administration of his business." 
and big businesses. ${ }^{84}$ Secondly, low cost and fast transports throughout Europe have made possible for natural persons to dissociate their habitual residences from the State in which they undertake economic activities ${ }^{85}$ In order to increase COMI predictability, the Insolvency Regulation Recast introduces two new presumptions for over-indebted natural persons. ${ }^{86}$ The COMI of individuals "exercising an independent business or a professional activity" is "presumed to be that individual's principal place of business" "87; this is a place where economic activities are managed and which is ascertainable by creditors, while the personal habitual residence is unsuitable for this purpose. ${ }^{88} \mathrm{By}$ contrast, COMI of over-indebted private persons and consumers is presumed to be in the country of their habitual residence, unless the contrary is proved. Case law in most Member States already follows similar presumptions and distinguish self-employed from other private persons. ${ }^{89}$

Recital 30 to the Insolvency Regulation Recast stresses that for rebutting the presumption it is not sufficient that "the major part of the debtor's assets is located outside the Member State of the debtor's habitual residence". To understand these mechanisms, it is worth recalling that rebuttable presumptions are more effective when they are based upon 'basic facts' that are either certain, like a company's registered office, or that can be easily proved..$^{90}$ Regarding self-employed private persons, the presumption might prove effective, since the principal place of business is often an official and clearly ascertainable place. ${ }^{91}$ With regard to private persons, however, the concept of ha-

84 Tribunals seem to be full of cases of German self-employed or private persons who tried shifting their COMI to Member States in which debt relief period is shorter than in Germany (where it is still of 6 years, unless the debtor pais $25 \%$ of her debts). There are even professional services helping private person to move from Germany to Elsass in France, where the discharge proceeding is apparently much faster; see, for instance: http://www.insolvenzinfrankreich.de/frankreich-insolvenz.html.

85 See Wessels (supra note 73) 467.

86 Insolvency Regulation Recast, article 3(1) sub-paragraph 4.

87 Insolvency Regulation Recast, article 3(1) sub-paragraph 3.

88 Wessels (supra note 74) 467-468; Moss - Fletcher -Isaacs, The EC regulation (note 35, 260; Moss - Paulus, 'The European Insolvency Regulation: The case for urgent reform', Insolvency Intelligence (2006) 2. See also Virgos - Schmit Report \$75: "In principle, the centre of main interests will in the case of professionals be the place of their professional domicile and for natural persons in general, the place of their habitual residence."

89 See also: Virgos - Schmit Report $\$ 75$.

90 See Adran Keane \& Paul McKeown, The Modern Law of Evidence, Oxford University Press, 2014, 672-673: once evidence of a certain "basic fact" is provided, another fact is considered existing.

91 See also Hess, Jurisdiction - Article 3 Insolvency Regulation, in Heidelberg/Vienna Report (note 20) 74, n. 299, who suggests adopting the place of registration when self-employed persons are registered as businessmen or professionals in public registers. 
bitual residence is less easy to ascertain and should be proved on a case-by-case basis. Certainly, this criterion must not be confused with any residence in which the debtor lives or spends time; debtors' habitual residences are rather their "settled, permanent home" where they live with their families, or "the place where [they return] from business trips". ${ }^{92}$

\section{c. Opportunistic and fictive COMI relocations}

It is still debated whether COMI relocations are - or may be - efficient and desirable. When debtors transfer their head office just before filing for insolvency, the doubt arises that such relocation was undertaken opportunistically at creditors' expenses or that it was a fictive transfer. ${ }^{93}$ While sophisticated or "adjusting" creditors can easily protect themselves against such relocations by adding protective covenants or requiring guarantees ${ }^{94}$, other creditors risk of being harmed by any changes of applicable insolvency law. On the other hand, a more efficient and value-enhancing insolvency regime could become applicable after a COMI transfer, to the advantage of all stakeholders. In this regard, one of the goals of the Insolvency Regulation is avoiding "incentives for the parties to transfer assets or judicial proceedings from one Member State to another, seeking to obtain a more favourable legal position"95 and the Insolvency Regulation Recast specifies that forum shopping should be avoided only

92 Re Stojevic [2007] BPIR 141, 59.

93 Gerald McCormack, 'Jurisdictional Competition and Forum Shopping in Insolvency Proceedings', 68 Cambridge Law Journal (2009), at p. 191; Horst Eidenmüller, 'Abuse of Law in European Insolvency Law', European Company Financial Law Review (2009) at p. 13, according to whom, "redistributive" COMI transfers are to be considered abusive; R.J. De Weijs - M.S. Breeman, 'COMI-migration: Use or Abuse of European Insolvency Law', European Company Financial Law Review (2014), who develop a sophisticated theory for distinguishing abusive from non-abusive COMI transfers following the blueprint of Eidenmüller proposal (a relocation is legitimate if it aims to better deal with the 'anticommons' creditors' problem, while it is to be considered as abusive if it aims at redistributing values among creditors).

94 Wolf-Georg Ringe, 'Forum shopping under the EU insolvency regulation', European Business Organization Law Review (2008); Marek Szydło, 'Prevention of Forum Shopping in European Insolvency Law’ 11 European Business Organization Law Review (2010), 253.

95 Recital 5 Insolvency Regulation Recast (formerly Recital 4 Insolvency Regulation). See also: European Parliament Resolution 2011, Recital A: “disparities between national insolvency laws create competitive advantages or disadvantages and difficulties for companies with cross-border activities [which] favour forum shopping;[...]“, and Recital B: "[...] steps must be taken to prevent abuses, or any spread, of the phenomenon of forum shopping". 
if detrimental to the general body of creditors. This amendment seems confirming that the primary purpose of the Insolvency Regulation is an efficient and effective management of insolvency proceedings and that avoiding forum shopping is an ancillary goal to this general purpose. ${ }^{96}$ Nevertheless, the question of how to deal with the risk of relocations in the vicinity of insolvency and with 'fictive' relocations is still open.

In order to avoid opportunistic relocations made just before the filing, both INSOL and the European Parliament proposed to move up the day as to which assessing a debtor's COMI, from the date of filing for insolvency ${ }^{97}$ to a previous date, by introducing a 'suspect period'. ${ }^{8}$ In the INSOL proposal, any transfer undertaken less than one year before filing for insolvency should have no impact upon jurisdiction, unless all pre-existing creditors explicitly agree to this COMI migration. ${ }^{99}$ The European Parliament recommended that debtors' COMI should be the place where they conduct the administration of their interests on regular basis "at least three months prior to the opening of insolvency proceeding or provisional proceeding”. ${ }^{100}$

The Insolvency Regulation Recast, by contrast, follows the different strategy of posing time limits to the presumptions of debtors' COMI. More precisely: (a) the presumption that a company's registered office is its COMI does not apply to companies reincorporating abroad within a period of three months

96 Eidenmüller, note 93, at p. 14.

97 The reference day as to which assessing a debtor's COMI is the date of filing for insolvency according to CJEU's case law: C-1/04 Staubitz-Schreiber [2006] ECR I-00701 (EU:C:2006:39); C-396/09, Interedil Srl, in liquidazione, v. Fallimento Interedil Srl, Intesa Gestione Crediti SpA, [2011] ECR I-9915 (EU:C:2011:671).

98 Marc-Philippe Weller, 'Forum shopping im internationalen Insolvenzrecht?', IPRax (2004) p. 412 et seq., at p. 416 suggested that debtors' COMI should be assessed as to the day when the insolvency becomes imminent and unavoidable.

99 INSOL, Revision of the Insolvency regulation - Proposals by INSOL, 2012, article 3(1): "[...] only the courts of the Member State where the centre of main interests was located one year prior to the request have jurisdiction to open insolvency proceedings under this paragraph provided the debtor has left unpaid liabilities caused at the time its centre of main interests was located in this Member State and unless (i) all creditors of these unpaid liabilities have agreed in writing to the transfer of the centre of main interests out of this Member State; or (ii) the debtor is a company or legal person and has moved its registered office to the Member State of its new centre of main interests more than one year prior to the request for opening of the proceedings."

100 European Parliament Resolution 2014, amendment 27. Such "suspect periods", however, are as arbitrary as any "one size fits all” solutions: Dario Latella, "The "COMI" concept in the Revision of the European Insolvency Regulation', European Company Financial Law Review (2014), at 490. Furthermore, if a company relocates its COMI by way of a transfer of its registered office, creditors are protected by the tenth directive on cross-border mergers (while in all other cases the introduction of a "suspect period” might be useful): Eidenmüller, 'Abuse of Law' (note 93) at p. 25. 
before filing for insolvency ${ }^{101}$; (b) if private professionals transfer their principal place of business abroad within a period of three months before filing for insolvency, the presumption that this place is their COMI does not apply; (c) with regard to other over-indebted individuals (including consumers), the presumption that their habitual residence is their COMI shall not apply if they relocated their habitual residence abroad within a period of six months before filing for insolvency. ${ }^{102}$ Regarding companies and professionals, however, a timespan of three months could prove too short. Insolvency, indeed, is rarely a sudden event and debtors, especially sophisticated ones, can normally predict far in advance whether they risk becoming insolvent. ${ }^{103}$ Therefore, companies can forecast their insolvency and may transfer their registered offices more than three months before they actually become insolvent, with the explicit aim of triggering the presumptions.

The new definition of COMI might have an impact upon fictive relocations. Indeed, the concept of COMI requires temporal stability of the new head office and, therefore, only genuine and permanent relocations of managerial functions are deemed COMI transfers. ${ }^{104}$ As we have seen above, however, in the original definition of COMI a causality relation linked permanence and ascertainability. The consequence was also that the ascertainability criterion plaid a paramount role in CJEU's case law and was considered evidence of a COMI's permanence in a certain place. The new definition of COMI, by contrast, repeals the causality relation between permanence and ascertainability with the consequence that temporal stability is now an autonomous and independent criterion. Therefore, courts should assess separately that the new head office has gained a certain degree of temporal stability and that such head office is ascertainable by third parties. As a consequence of this new definition of COMI, when a company transfers abroad its head office without relocating its registered office, it should be more burdensome rebutting the presumption of coincidence with the registered office by providing the evidence that its COMI was also relocated.

101 Insolvency regulation Recast, article 3 (1), sub-paragraphs 2 and 3. This presumption is in Article 3 (1) Insolvency Regulation.

102 Insolvency regulation Recast, article 3 (1), sub-paragraphs 2 and 3.

103 See: Edward Altman \& Edith Hotchkiss, Corporate Financial Distress and Bankruptcy: Predict and Avoid Bankruptcy, Analyze and Invest in Distressed Debt, Wiley 2006, 3rd edition, p. 233 et seq.

104 Virgos \& Garcimartin, The European Insolvency Regulation (note 70) 51; Marek Szydło, 'Prevention of Forum Shopping in European Insolvency Law', (note 94) at p. 258-259. 


\section{Scope of insolvency law and insolvency-related actions}

\section{a. Actions related to insolvency proceedings in the CJEU's case law}

The Member State where a debtor' COMI is situated shall govern insolvency's procedural issues, such as conditions for opening an insolvency proceeding, rules for conducting and closing the procedures. Furthermore, the Insolvency Regulation enumerates a non-exhaustive list of topics that are related to the insolvency procedure and are therefore governed by the State of the COMI. ${ }^{105}$ In this regard, the question arises of whether other issues that are not included in that list also shall be governed by the law of the State where the COMI is situated. At a more theoretical level, the main question is tracing the boundaries between insolvency law rules and company law rules for private international law purposes. In particular, the private international law classification of several national provisions aimed at protecting creditors from directors' decisions taken in the vicinity of insolvency might be unclear and might vary from State to State.

To understand the relevance of this issue, it is worth reminding that, according to CJEU's case law on freedom of establishment, companies are governed by company law rules of the Member State of incorporation even when their business is entirely in another country ('pseudo-foreign companies'). ${ }^{106}$ The State of a company's activity can only apply domestic company law rules if such application is non-discriminatory, if it is based upon 'imperative requirements in the general interest' and is 'proportionate' for attaining such goals. ${ }^{107}$ Member States where 'pseudo-foreign companies' undertake their business activities, however, are not unarmed. In order to apply own standard of creditor protection to foreign companies, indeed, Member States might employ insolvency law rules, instead of company law strategies ${ }^{108}$, or might 're-classify' domestic company law rules as 'insolvency law' for private international

105 Insolvency Regulation Recast, article 7 (formerly article 4)

106 C-212/97, Centros Ltd v Erbvervsog Selskabsstyrelsen [1999] ECR I-1459; C-208/00, Überseering BV v Nordic Construction Company Baumanagement GmbH [2002] ECR I-9919; C-167/01, Kamer van Koophandel en Fabrieken voor Amsterdam v. Inspire Art, [2003] ECR I-1095.

107 C-55/94, Reinhard Gebhard v. Consiglio dell'Ordine degli Avvocati e Procuratori di Milano, C-55/94, [1995] ECR I-04165.

108 Company law rules in EU Member States might also aim at protecting creditors and other stakeholders, not only at regulating the internal relation between shareholders and directors: Federico M. Mucciarelli. 'The Function of Corporate Law and the Effects of Reincorporations in the U.S. and the EU', 20 Tulane Journal of International and Comparative Law (2012), 456-458. 
law purposes only. ${ }^{109}$ In these cases, domestic creditor protection strategies would apply to insolvent foreign companies having their COMI on the domestic territory. Therefore, a clear distinction between 'insolvency-related' issues and 'company law' issue at EU level is necessary for clarifying this grey area.

The question of the applicable substantive law is intertwined with the jurisdiction on actions related to the insolvency proceeding. In this regard, as we have seen above, the scopes of the Brussels I Regulation and the Insolvency Regulation are mutually exclusive. ${ }^{110}$ In this regard, the CJEU has stated that the Member State of a debtor's COMI has jurisdiction to hear actions that "derive directly from the bankruptcy or winding-up and [are] closely connected with the proceedings". ${ }^{111}$ In several decisions, the CJEU has further specified the concept of connected actions and has introduced a EU-wide vis attractiva concursus regarding international jurisdiction on insolvency matters. $^{112}$

These decisions, however, were related to jurisdictional issues, not to the applicable substantive law. Therefore, the question arises of whether the criterion used to establish a court's international competence is also relevant for determining the applicable law. An answer might be found in the recent CJEU's decision rendered in the case Nickel. ${ }^{113}$ In an effort of systematically restate previous case law, the CJEU maintained that the decisive criterion for identifying "the area within which an action falls [i.e. whether insolvency or company law] is not the procedural context of which that action is part, but the

109 Carsten Gerner-Beuerle \& Edmund-Philipp Schuster, 'The costs of separation: friction between company and insolvency law in the single market', Journal of Corporate Law Studies, 2004, 302.

110 Article 1(2)(b) Brussels I Regulation Recast. See: C-133/78, Gourdain v. Nadler [1979] R-I 733; C-157/13, Nickel \& Goeldner Spedition GmbH v. "Kintra" UAB (EU:C:2014:2145); see also the decisions mentioned at note 113 hereunder.

111 C-133/78, Gourdain v. Nadler [1979] R-I 733, at 4.

112 The CJEU has recognised that following actions fall within the scope of the Insolvency Regulation: directors' liability for breach of duties arising in the vicinity of insolvency (Gourdain decision, see note 109); avoidance actions to the benefit of the general body of creditors (C-339/07 Seagon v. Deko Marty Belgium, ECR 2009 I-767 (EU:C:2009:83); see also: C-213, F-Tex SIA v Lievtuvos-Anglijo UAB "JadecloudVilma" (EU:C:2012:215), in which the court did not qualify the specific action as closely linked to an insolvency proceeding); action to recover ownership of shares in a foreign company (C-111/08, SCT Industri AB v. Alpenblume, ECR 2009 I-5655); directors' liability for payment after a company has become insolvent, under $\$ 64(2)$ GmbHG [German Act on Private Companies] C-296/13 H. v. H.K. (EU:C:2013:580). For a discussion see: Gerard McCormack, 'Reconciling European Conflicts and Insolvency Law', 15 European Business Organization Law Review (2014) 320-325.

113 C-157/13, Nickel E Goeldner Spedition GmbH v. "Kintra” UAB (EU:C:2014:2145) 
legal basis thereof", with the consequence that the international competence depends on "whether the right or the obligation which respects the basis of the action finds its source in the common rules of civil and commercial law or in the derogating rules specific to insolvency proceedings". ${ }^{114}$ This decision clarifies that the jurisdictional criterions should coincide with the scope of substantive rules; the Nickel decision, furthermore, seems implying that jurisdictional criterions proceeds from the substantive law classifications, not vice versa. This conclusion, however, is still uncertain and, therefore, the relation between jurisdictional criterions and scope of substantive law rules for actions 'related' to an insolvency proceeding still needs to be clarified. In this regard, the German BGH [Federal Court of Justice] has recently submitted to the CJEU a request for preliminary ruling ${ }^{115}$, asking whether German provisions on directors' liability for payments made after insolvency also apply to English Ltd companies having their COMI in Germany. ${ }^{116}$ The CJEU clarified that this directors' liability is to be classified as 'insolvency law' according to article 4 Insolvency Regulation (article 7 Insolvency Regulation Recast). ${ }^{17}$ In particular, the CJEU maintained that both a duty to file for insolvency and 'the consequences of an infringement of that obligation' fall within the 'conditions for the opening of the insolvency proceedings'.

Eventually, it is worth mentioning that the CJEU, in a recent decision rendered in the case Nortel ${ }^{118}$, has addressed, among other questions, the criterions for establishing whether an action is 'related' to a secondary proceeding. This decision clarifies that the object of secondary proceedings is protecting 'local interests'. Additionally, the Nortel decision maintains that actions that assess where certain assets are situated, and therefore that establish whether these assets fall within the competence of a secondary proceeding, are "designed specifically to protect these interests [i.e. local interests]". ${ }^{119}$ Therefore, such actions are to be considered actions 'related' to the secondary proceeding. The CJEU, therefore, lays down a 'teleological' criterion: an action is related to a secondary proceeding when it aims at attaining the same goals of that proceeding (protecting local creditors). Differently from secondary proceedings, however, main proceedings pursue the 'general' goals of addressing creditors' collective action problems, restructuring or liquidating the insolvent company and distributing assets among all creditors. Therefore, the Nortel criterion is difficultly applicable to assessing whether an action is 'related' to a main proceeding and should be further developed and specified.

114 Case Nickel, supra note 109, at 27. See: Jonathan Fitchen, supra note 58, at p. 70.

115 BGH 2.12.2014 - II ZR 119/14 “Kornhaas"; C-594/14, OJ C127, 20.4.2015, p.7.

$116 \$ 64(2)$ of the German Act on Private Companies (GmbHG).

117 C-594/14, Kornhaas v Dithmar (EU:C:2015:806)

118 C-649/13, Comite' d'enterprise de Nortel Networks SA v. Rogeau (EU:C:2015:384).

119 C-649/13 (note 116), at 36. 


\section{b. Scope of insolvency law rules and insolvency-related actions in the Insolvency Regulation Recast}

The Insolvency Regulation Recast introduces several provisions aimed at clarifying the scope of insolvency law and insolvency-related actions. First of all, the Insolvency Regulation Recast maintains that courts "of the Member States within the territory of which insolvency proceedings have been opened [...] shall have jurisdiction for any action which derives directly from the insolvency proceeding and is closely linked with them, such as avoidance actions". ${ }^{120}$ This provision codifies the 'Gourdain formula' and the international vis attractiva concursus laid down in the Deko-Marty decision. The Insolvency Regulation Recast, however, does not specify the criterions for assessing whether an action 'derives directly' from, or is 'closely linked' with, an insolvency proceeding. ${ }^{121}$

As a partial clarification, Recital 35 stresses that courts of the State of a debtor's COMI have jurisdiction to hear any "actions concerning obligations that arise in the course of the insolvency proceedings", even though the defendant is situated in another Member State. This recital, however, is probably trivial and does not address duties arising before the commencement of an insolvency proceeding, such as directors' duties and liabilities arising in the vicinity of insolvency and aimed at protecting creditors.

Eventually, the Insolvency Regulation Recast specifies that "actions are deemed to be related where they are so closely connected that it is expedient to hear and determine them together to avoid the risk of irreconcilable judgments resulting from separate proceedings". ${ }^{122}$ The 'risk of irreconcilable judgements' criterion is based upon a factual and 'purpose-based' assessment of whether a decision rendered by courts of a certain State is not compatible with decisions taken by the court of the main insolvency proceeding. Such provision mirrors an identical criterion that is included in the Brussels I Regulation for claims against co-defendants ${ }^{123}$ and that derives from the CJEU decision Kalfelis $v$ Bankhaus. ${ }^{124}$ The precise contours of the criterion drawn by the Brussels I Regulation are however still uncertain in CJEU case law. Indeed,

120 Article 6(1) Insolvency Regulation Recast.

121 See the criticisms of McCormack 'Reforming' (note 26) 51 and 'Reconciling' (note 115) 333.

122 Article 6(3) Insolvency Regulation Recast.

123 Article 8(1) Brussels I Regulation Recast: “A person domiciled in a Member State may also be sued [...] where he is one of a number of defendants, in the courts for the place where any one of them is domiciled, provided the claims are so closely connected that it is expedient to hear and determine them together to avoid the risk of irreconcilable judgments resulting from separate proceedings".

124 C-189/87, Kalfelis v Bankhaus Schröder, Münchmeyer, Hengst E Co [1988] ECR 5579. 
while some CJEU decisions maintain that, in order to consider actions against multiple defendants as closely connected, the 'same situation of law and fact' should exist ${ }^{125}$, other decisions accept that the actions might not have identical legal base ${ }^{126}$ and might be governed by substantive rules of different States. ${ }^{127}$ The 'risk of irreconcilable judgements' criterion, therefore, can not fully clarify when an action 'derives directly' from an insolvency proceeding or is deemed 'closely linked' to an insolvency proceeding.

The main problem, however, is that the new rules of the Insolvency Regulation Recast only address international jurisdictional issues, but it is not clear whether these criterions also establish the applicable substantive law. In particular, the private international law criterion to be applied to directors' duties and liabilities in the 'twilight' zone before insolvency is still unclear. A closer view has revealed that most of the provisions of the Recast simply codify previous case law and do not fully answer all questions that have arisen so far. EU political bodies, therefore, by amending the Insolvency Regulation have not made use of an opportunity for clarifying several unresolved questions regarding jurisdictional criterions and conflict of law criterions for actions 'related' to insolvency proceedings.

\section{Territorial proceedings and 'synthetic secondary proceedings'}

As outlined above, territorial proceedings limited to local assets can be opened in Member States where debtors' establishments are situated. ${ }^{128}$ One of the raison d'être of territorial proceedings is protecting local preferential creditors from the risk that the State of the COMI follows different distributional

125 C-539/03, Roche Nederland BV v Primus [2006] ECR I/6569.

126 C-98/06, Freeport plc v Arnoldsson [2007] ECR I-8319.

127 C-145/10, Painer v Standard Verlags GmbH [2011] ECR I-12594,

128 According to the original version of the Insolvency Regulation, article 2(h), 'establishment' was "any place of operations where the debtor carries out a non-transitory economic activity with human means and goods." In the Insolvency Regulation Recast, article 2(10), an 'establishment' is "any place of operations where a debtor carries out or has carried out in the three month period prior to the request to open main insolvency proceedings a non transitory economic activity with buman means and assets". The differences are the following: (a) the concept of "goods" is replaced with "assets" (the Recast does not upheld the suggestion made by Insol Report and European Parliament of adding services); (b) besides places where debtors presently carry out activities, also places where they have "carried out in the three months prior to the request to open main insolvency proceedings a non-transitory economic activity with human means and assets" can be held as establishments (by using the present perfect, the Reform refers to an activity undertaken in an unspecified time before the filing or continuing up to that moment, not to activities completely finished in the past prior to the filing). 
criteria and does not prioritise their claims. ${ }^{129}$ A typical example is employee priority for due wages: while some States prioritise due wages over other claims, other insolvency regimes do not foresee any employee priority. Therefore, when the State of the COMI provides for weaker priorities, or for no priorities at all, employees working in another Member State have an interest in filing for a secondary proceeding in the State of their establishment. ${ }^{130}$ Eventually, secondary proceedings may aim at obtaining a stay of secured creditors' claims in relation to assets situated in the State of the establishment, to the advantage of local creditors. ${ }^{131}$ The opening of a secondary territorial procedure, however, could increase the overall costs of the procedure and could jeopardise rescue attempts undertaken by the court of the main proceeding.

\section{a. Scope of secondary proceedings}

A major obstacle in the way of effectively implementing rescue plans was that, under the original version of the Insolvency Regulation, secondary proceedings could only pursue liquidation purposes. ${ }^{132}$ The CJEU has addressed this issue in a decision rendered in the case Bank Handlowy, which dealt with a French company that indirectly controlled a Polish company. ${ }^{133}$ A French court held that the subsidiary's COMI was in France and, consequently, it opened a proceeding aimed at rescuing the whole group of companies according to French law. Nevertheless, creditors of the Polish subsidiary filed for a secondary proceeding in Poland. The CJEU acknowledged that the opening of territorial proceedings for liquidation purposes "risks running counter to the purpose served by main proceedings"; the only solution, however, was found in the principle of sincere cooperation laid down in the Treaty on the Functioning of the European Union ${ }^{134}$, which, according to the CJEU, "requires the court having jurisdiction to open secondary proceedings, in applying those

129 See Jose' M. Garrido, 'The Distributional Question in Insolvency: Comparative Aspects', 4 International Insolvency Review (1995) 25 et seq.

130 See, for instance: Michel Menjucq \& Reinhard Dammann, 'Regulation No. 1346/2000 on Insolvency Proceedings: Facing the Companies Group Phenomenon', 9 Bus. L. Int'l (2008) 154.

131 On the immunity for third parties' rights in rem (article 8 Insolvency Regulation Recast, formerly article 5 Insolvency Regulation) see Michael Veder, Cross-border insolvency proceedings and security rights (Kluwer 2004).

132 Goode, Principles of corporate insolvency law (note 39) at 15-60; Ian Fletcher, Insolvency in Private International Law (Oxford, 2005) 371.

133 The French company owned $90 \%$ of a German company, that owned $100 \%$ of the capital of the Polish company.

134 Article 4(3) Treaty on the Functioning of the European Union. 
provisions, to have regard to the objectives of the main proceedings" ${ }^{135}$ The fact that CJEU refers to general principles of EU law shows that the Insolvency Regulation did not effectively coordinate secondary and main proceedings.

The Insolvency Regulation Recast addresses this issue by repealing the provision that secondary proceedings should have liquidation purposes and by increasing coordination duties. Therefore, secondary proceedings can now aim at helping the main proceeding in reorganising an indebted company. Coherently, the Insolvency Regulation Recast increases the duties of cooperation between insolvency practitioners and courts of main and secondary proceedings, which can conclude binding agreements. ${ }^{136}$ Furthermore, insolvency practitioners of main proceedings have the power of intervening in secondary proceedings ${ }^{137}$, of proposing a restructuring plan or requesting a conversion into another type of procedure. ${ }^{138}$

\section{b. Synthetic secondary proceedings}

The most significant innovation is the introduction of 'synthetic secondary proceedings' ${ }^{139}$ whereby the insolvency practitioner of a main proceeding can avoid the opening of secondary proceedings in Member States where a debtor's establishments are situated. ${ }^{140}$ To this aim, insolvency practitioners of main proceedings can undertake that they will respect "distribution and priority rights [of the Member State] in which secondary proceedings could be

135 Bank Handlowy, paragraph 62.

136 Article 41 and article 42 Insolvency Regulation Recast.

137 Article 38(3) Insolvency Regulation Recast.

138 Articles 47 and 51 Insolvency Regulation Recast

139 Commission Proposal, Explanatory Memorandum, page 7. Prof. Wessels suggests to label these proceedings "as if proceedings", because they aim at treating creditors located in another Member State "as if" secondary insolvency proceedings had been opened: Wessels, 'Contracting out' (note 6). Among legal scholars, a similar approach was suggested by Edward J. Janger, 'Virtual Territoriality', 48 Columbia Journal of Transnational Law (2010) 401, 422 (substantive law should be determined according ordinary choice-of-law-rules, while the procedure should be heard exclusively by courts of the State of the COMI). See however: Eidenmüller, 'A New Framework' (note 26) 147 (synthetic secondary proceedings are second-best solutions).

140 Insolvency practitioners can also request courts of secondary proceedings to suspend liquidating local assets. In these cases, courts of secondary proceedings can request the insolvency practitioner "to take any suitable measure to guarantee the interests of the creditors in the secondary proceedings and of individual classes of creditors", among which are undertakings to apply local priority rules. Article 33 Insolvency Regulation (now article 46 Insolvency Regulation Recast). Moss - Fletcher - Isaacs, The EC regulation (supra note 35 ) p. 116. 
opened" having regard to assets situated in such States. ${ }^{141}$ These undertakings can not replicate all effects produced by 'real' secondary proceedings, such as a moratorium of secured and unsecured claims, and can only mimic their distributional criterions. An undertaking should be approved by creditors "whose claims against the debtor arose from or in connection with the operation of an establishment" ('local creditors') ${ }^{142}$ according to procedural rules that apply to rescue procedures of the State of the establishment. ${ }^{143}$ Despite the approval of 'local creditors', courts of Member States where establishments are situated retain the power of opening a secondary proceeding unless they are "satisfied that the undertaking adequately protects the general interests of local creditors". ${ }^{144}$

This innovation is based upon recent English decisions ${ }^{145}$, which accepted that domestic liquidators distributed debtors' assets to unsecured creditors according to priority rules of Member States in which debtors' establishments were situated. In return, creditors abstained from filing for secondary proceedings. These English decisions, however, dealt with insolvent groups of companies having subsidiaries in different Member States ${ }^{146}$, addition their main goal was attaining a procedural consolidation of groups' insolvencies, without pooling all companies' assets. ${ }^{147}$ In these cases, therefore, each establishment had separate legal personality, and both local creditors and assets of the establishment were easily isolated from other creditors and from assets of other companies.

141 Article 36 Insolvency Regulation Recast.

142 Article 2(11) Insolvency Regulation Recast.

143 Article 36(5) Insolvency Regulation Recast.

144 Article 38(2) Insolvency Regulation Recast. See: Edward J. Janger, 'Silos: Establishing the Distributional Baseline in Cross-Border Insolvencies', 9 Brook. J. Corp. Fin. E Com. Law. (2014) 102. Furthermore, courts of Member States where a debtor has an establishment can suspend the decision to open a secondary proceeding, when a temporary stay is decided in the main proceeding, but only if "suitable measures are in place to protect the interests of local creditors". Among such "suitable measures" the court of the establishment can also request the insolvency practitioner of the main proceeding to issue an undertaking under article 36 of the Insolvency regulation: Article 38 (3) first paragraph Insolvency Regulation Recast.

145 Re MG Rover Belux SA/NV (in admin.) [2007] B.C.C. 446.; Re Collins E Aikman Corporation Group [2005] EWHC 1754 (Ch); Re Nortel Network [2009] EWHC (Ch) 206.

146 A subsidiary can be considered an establishment of the holding company, if it meets the criteria set out in the Insolvency Regulation; see: CJEU C-327/13, Burgo Group SpA v. Illochroma SA [2014] ...

147 See: Irit Mevorach, 'Approprate Treatment of Corporate Groups in Insolvency: A Universal View', 8 European Business Organization Law Review (2007) 189 and Insolvency within Multinational Enterprise Groups (Oxford, 2009) 248; Heribert Hirte, 'Towards a Framework for the Regulation of Corporate Groups' Insolvencies', European Company Financial Law Review (2008) 218-219. 
By contrast, when establishments do not have separate legal personalities and are just branches of a single company that has become insolvent, the insolvency proceeding "concerns one debtor with one estate and one group of creditors". ${ }^{148}$ Therefore, each establishment's estate is not 'ring-fenced' from general creditors or from creditors of other branches ${ }^{149}$, with the consequence that isolating 'local creditors' from other creditors is a much more complex task.

Another relevant problem is assessing in which Member States assets are situated, since undertakings to respect local priorities are limited to "assets located in the Member State in which secondary insolvency proceedings could be opened". Therefore, 'local' creditors suffer losses if substantial assets are located in other States or are shifted abroad. ${ }^{150}$ In this regard, however, the Insolvency Regulation Recast has reduced the uncertainties surrounding the notion of 'Member States in which assets are situated'. ${ }^{151}$ The general rule for property rights on assets is based upon an asset' physical presence on a certain Member State ${ }^{152}$, but several special rules specify this general principle. The original Insolvency Regulation provided for two further criterions: (1) property rights and entitlements entered in a public register (such as rights on immovable goods) are located in the State under which authority the register is kept; (2) claims against third parties are in the Member State within whose territory the centre of the debtor's main interests is situated. The Insolvency Regulation Recast introduces other criterions for uncertain cases: (1) regarding shares and other financial instruments, the Insolvency Regulation Recast distinguishes securities "the title to which is evidenced by entries in a register or account maintained by or on behalf of an intermediary" (book entry securities) from other registered shares: book entry securities are located in the State of the register or of the account, while other shares are located in the State of the company's registered office; (2) cash hold in a bank account is considered being located in the Member State of the bank's IBAN code ${ }^{153}$; (3) European patents are located in the State "for which the patent is granted".

148 Wessels, 'Contracting out' (note 6) 244.

149 Any creditors can lodge their claims in both main and territorial proceedings according to article 45 Insolvency Regulation Recast.

150 See the criticisms of Jay Lawrence Westbrook, 'A Comment on Universal Proceduralism’, 48 Columbia Journal of Transnational Law (2010) 505.

151 Article 2(9) Insolvency Regulation Recast, which has repealed former Article 2(g) of Insolvency Regulation.

152 Article 2(g) Insolvency Regulation.

153 While cash held with an account at a bank without an IBAN code (e.g. U.S. and Canadian banks), is considered located in the Member State "in which the credit institution holding the account has its central administration or, where the account is held with a branch, agency or other establishment, the Member State in which the branch, agency or other establishment is located". 
These criterions, whose impact deserves a deeper analysis, certainly specify and clarify pre-existing rules. Nevertheless, these new criterions are likely not to be complete and all-inclusive. For instance, they would not provide an answer to situations like that faced by the CJEU in the Nortel case, in which a right to use non-European patents was under discussion. Such rights could have been characterised either entitlements on registered assets or claims against third parties. Therefore, the risk still exists that courts of different Member States issue conflicting decisions as to the place where certain assets are situated, as a consequence of different characterisation of those assets. As a partial answer, the conclusions of AG Mengozzi to the Nortel case identified the general criterion, to be applied to uncertain cases, that debtors' assets are situated in the State with which they have the closest connection. ${ }^{154}$ This criterion, however, was not mentioned by the CJEU in its final decision, with the consequence that domestic court will decide on uncertain cases according to domestic criterions, without any general guidelines rooted on EU law.

\section{Conclusions: lights and shadows of a minimal approach}

Although the Insolvency Regulation Recast includes relevant innovations, such as a common insolvency register or a special procedure for corporate groups, this reform does not alter the fundamental logic of the original regulation, which aims at creating a coherent private international law system for cross-border insolvencies in the EU.

Most changes to the original Insolvency Regulation codify CJEU's case law. This is the case, for instance, regarding the scope of the regulation: the Recast enlarges the general scope of the regulation laid down in article 1(1), but also codifies the principle that only proceedings included in Annex A fall within the scope of the regulation. The Recast also amends the definition of COMI, by including the criterions of permanence and ascertainability, which were formerly in Recital 13. However, the Insolvency Regulation Recast diverges from old Recital 13, since the criterion of ascertainability does not depend on time continuity. This amendment might be used as a barrier in the way of fictive relocations, since time continuity and ascertainability should be proved separately. In general, however, the Recast does not address 'opportunistic' COMI relocations, it only states that presumptions serving a COMI's assessment do not apply when debtors relocate their registered office, principal place of business or habitual residence few months before filing for insolvency.

154 C-649/13, Comite' d'enterprise de Nortel Networks SA v. Rogeau, conclusions of AG Mengozzi, n. 69-71. This argument was based upon art. 2(f) Insolvency Regulation as replaced by the Commission Proposal, which was almost identical to art. 2(9) Insolvency Regulation Recast. 
The Insolvency Regulation Recast misses the opportunity of precisely clarifying the boundaries between the scope of insolvency law (lex concursus) and the scope of company law (lex societatis) for private international law purposes. The Recast only codifies the CJEU's 'Gourdain formula' and the vis attractiva concursus. The only innovation is the 'risk of irreconcilable judgement' criterion, which replicates a criterion already included in the Brussels I Regulation. Such provisions, however, only refer to international jurisdictional questions and do not clearly address the international scope of substantive insolvency rules.

The Insolvency Regulation Recast is more innovative regarding secondary proceedings, by allowing opening secondary proceedings with rescue purposes and introducing 'synthetic secondary proceedings', aimed at avoiding the opening of secondary proceedings. The mechanism of 'synthetic secondary proceedings', however, require that (a) 'local creditors' of the establishment are distinguished from other creditors and (b) assets located in the Member State of the establishment are clearly identified. These questions may be shrouded in uncertainty, unless the 'establishment' has own legal personality, in which case, however, the special coordination procedure for groups of companies is probably more effective and is likely to be preferred. In general, 'synthetic secondary proceedings' might represent a 'baseline' of distributional criterions for insolvent companies having branches in different Member States, but the uncertainties described so far are likely to make their application rare.

The overall impression is that, with few exceptions, the Insolvency Regulation Recast does not drastically alter the private insolvency law scenario for crossborder insolvencies. The impact of most important private international law innovation (synthetic secondary proceedings and the new COMI definition) is likely to depend on how national courts will apply these new provisions. We can expect, therefore, that in the next years the CJEU will continue playing a pivotal role in the development of the EU insolvency private international regime. 